\title{
Particulate matter 2.5 damages skin cells by inducing oxidative stress, subcellular organelle dysfunction, and apoptosis
}

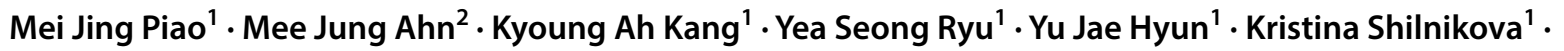 \\ Ao Xuan Zhen ${ }^{1} \cdot$ Jin Woo Jeong ${ }^{3} \cdot$ Yung Hyun $\mathrm{Choi}^{3} \cdot$ Hee Kyoung Kang $^{1} \cdot$ Young Sang Koh ${ }^{1} \cdot$ Jin Won Hyun ${ }^{1}$
}

Received: 9 November 2017 / Accepted: 21 March 2018 / Published online: 26 March 2018

(c) The Author(s) 2018

\begin{abstract}
The skin is the largest organ of the human body and the one mostly exposed to outdoor contaminants. To evaluate the biological mechanisms underlying skin damage caused by fine particulate matter $\left(\mathrm{PM}_{2.5}\right)$, we analyzed the effects of $\mathrm{PM}_{2.5}$ on cultured human keratinocytes and the skin of experimental animals. $\mathrm{PM}_{2.5}$ was applied to human HaCaT keratinocytes at $50 \mu \mathrm{g} / \mathrm{mL}$ for $24 \mathrm{~h}$ and to mouse skin at $100 \mu \mathrm{g} / \mathrm{mL}$ for 7 days. The results indicate that $\mathrm{PM}_{2.5}$ induced oxidative stress by generating reactive oxygen species both in vitro and in vivo, which led to DNA damage, lipid peroxidation, and protein carbonylation. As a result, $\mathrm{PM}_{2.5}$ induced endoplasmic reticulum stress, mitochondrial swelling, and autophagy, and caused apoptosis in $\mathrm{HaCaT}$ cells and mouse skin tissue. The $\mathrm{PM}_{2.5}$-induced cell damage was attenuated by antioxidant $N$-acetyl cysteine, confirming that $\mathrm{PM}_{2.5}$ cellular toxicity was due to oxidative stress. These findings contribute to understanding of the pathophysiological mechanisms triggered in the skin by $\mathrm{PM}_{2.5}$, among which oxidative stress may play a major role.
\end{abstract}

Keywords $\mathrm{PM}_{2.5} \cdot$ Oxidative stress $\cdot$ Apoptosis $\cdot$ Endoplasmic reticulum stress $\cdot$ Mitochondrial damage $\cdot$ Autophagy

\section{Introduction}

Global air pollution has become a major threat to human health. This worldwide problem is especially relevant to the release of fine particulate matter $\left(\mathrm{PM}_{2.5}\right)$, which has the aerodynamic diameter less than $2.5 \mu \mathrm{m}$ and originates from incomplete coal combustion and diesel vehicle exhaust in Korea (Lee et al. 2005; Jung et al. 2017). In recent years, the relationship between $\mathrm{PM}_{2.5}$ production and public health hazards has attracted an increasing attention. Several toxicological and epidemiological studies have suggested that $\mathrm{PM}_{2.5}$ exerts negative biological effects on several major organs, including the lung (Liu et al. 2017), immune system

Jin Won Hyun

jinwonh@jejunu.ac.kr

1 Jeju National University School of Medicine and Jeju Research Center for Natural Medicine, Jeju 63243, Republic of Korea

2 Laboratory of Veterinary Anatomy, College of Veterinary Medicine, Jeju National University, Jeju 63243, Republic of Korea

3 Department of Biochemistry, College of Oriental Medicine, Dongeui University, Busan 47340, Republic of Korea
(Zhao et al. 2013), cardiovascular system (Du et al. 2016), and nervous system (Wang et al. 2017). Among the affected organs, the skin is the primary tissue exposed to ambient pollutants and, similar to the respiratory tract, presents an interface between the body and surrounding atmosphere.

$\mathrm{PM}_{2.5}$-carrying organic chemicals such as polycyclic aromatic hydrocarbons (PAHs) are highly lipophilic and easily penetrate the skin (Krutmann et al. 2014). PAHs are potent activators of the aryl hydrocarbon receptor (AhR), which is a ligand-dependent transcription factor expressed in keratinocytes and melanocytes (Fritsche et al. 2007; Jux et al. 2011). AhR activation by PAHs upregulates the expression of cytochrome P450 (CYP1A1) involved in the metabolism of xenobiotics (Vogel et al. 2016) and promotes generation of intracellular reactive oxygen species (ROS) (Costa et al. 2010). Accumulated evidence indicates that oxidative stress is a common mechanism of $\mathrm{PM}_{2.5}$-induced damage (Gualtieri et al. 2012; Kouassi et al. 2010). Recently, the effect of $\mathrm{PM}_{2.5}$ on the skin has attracted attention of both clinical dermatologists and basic scientists (Han et al. 2016; Li et al. 2017), who recognized ambient $\mathrm{PM}_{2.5}$ as a crucial risk factor in skin diseases. Thus, $\mathrm{PM}_{2.5}$ was shown to aggravate symptoms in children with allergic dermatitis and eczema (Song et al. 2011), and to promote inflammatory disorders, 
aging, androgenetic alopecia, and cancers of the skin (Kim et al. 2016).

Mitochondria are unique double-membrane subcellular organelles that provide energy through oxidative phosphorylation and participate in metabolic and genetic processes in the body. Once mitochondria are disrupted, their dysfunction leads to reduced generation of ATP and higher production of ROS. Mitochondria are targeted by environmental pollutants such as $\mathrm{PM}_{2.5}$ (Guo et al. 2017) and mitochondrial damage may be a critical part of the pathophysiological mechanisms induced by $\mathrm{PM}_{2.5}$ exposure. Oxidative stress has been shown to be an initiator and major contributor to both endoplasmic reticulum (ER) stress (Hotamisligil 2010; Kaneto et al. 2005) and lysosome-mediated autophagy (Lee et al. 2012); however, the research on molecular pathways linking atmospheric $\mathrm{PM}_{2.5}$ and skin damage is limited. Although skin is the organ mostly exposed to $\mathrm{PM}_{2.5}$, the association of skin-damaging effects of $\mathrm{PM}_{2.5}$ with oxidative stress and dysfunction of subcellular organelles such as mitochondria, $\mathrm{ER}$, and lysosomes is still not fully elucidated. In this study, we investigated the effects of $\mathrm{PM}_{2.5}$ on the induction of oxidative stress and structure of subcellular organelles using in vitro and in vivo models and explored the mechanisms underlying $\mathrm{PM}_{2.5}$ toxicity for the skin.

\section{Materials and methods}

\section{Preparation of $\mathrm{PM}_{2.5}$}

Diesel particulate matter NIST $1650 \mathrm{~b}\left(\mathrm{PM}_{2.5}\right)$ was purchased from Sigma-Aldrich, Inc. (St. Louis, MO, USA). $\mathrm{PM}_{2.5}$ stock solution $(25 \mathrm{mg} / \mathrm{mL})$ was prepared in dimethyl sulfoxide (DMSO) and sonicated for $30 \mathrm{~min}$ to avoid agglomeration of the suspended $\mathrm{PM}_{2.5}$ particles. Experiments were performed within $1 \mathrm{~h}$ of stock preparation to avoid variability in $\mathrm{PM}_{2.5}$ composition in solution.

\section{Cell culture}

Human HaCaT keratinocytes (Amore Pacific Company, Gyeonggi-do, Republic of Korea) were maintained at $37{ }^{\circ} \mathrm{C}$ in an incubator with a humidified atmosphere of $5 \% \mathrm{CO}_{2}$. Cells were cultured in Dulbecco-modified Eagle medium (DMEM) containing 10\% heat-inactivated fetal bovine serum and antibiotic-antimycotic (100 units/mL penicillin, $100 \mu \mathrm{g} / \mathrm{mL}$ streptomycin, and $0.25 \mu \mathrm{g} / \mathrm{mL}$ amphotericin B) (Gibco, Life Technologies Co., Grand Island, NY, USA).

\section{Animal experiment}

In vivo experiments were conducted using HR-1 hairless male mice (OrientBio, Kyungki-do, Republic of Korea) in accordance with the guidelines for the care and use of laboratory animals at Jeju National University (Jeju, Republic of Korea) (permit number: 2017-0026). Mice were randomly divided into three groups $(n=4$ each): control, and treated with $\mathrm{PM}_{2.5}$ or $N$-acetyl cysteine (NAC; SigmaAldrich) $+\mathrm{PM}_{2.5} . \mathrm{PM}_{2.5}$ was dispersed in propylene glycol to the concentration of $100 \mu \mathrm{g} / \mathrm{mL}$, spread on a nonwoven polyethylene pad over a $1 \mathrm{~cm}^{2}$ area, and applied to the dorsal skin of mice for 7 consecutive days. At the end of the treatment, the exposed skin tissue was immediately dissected for histological and biochemical analysis as previously described (Lee et al. 2016).

\section{ROS measurement}

Cells were incubated with different concentrations of $\mathrm{PM}_{2.5}$ $(25,50,75$, and $100 \mu \mathrm{g} / \mathrm{mL})$ for $24 \mathrm{~h}$ or treated with $\mathrm{PM}_{2.5}$ at a concentration of $50 \mu \mathrm{g} / \mathrm{mL}$ for different times $(1,2,4,8$, 12 , and $24 \mathrm{~h}$ ). After staining with $25 \mu \mathrm{M} \mathrm{2}$ 2', $^{\prime}$ '-dichlorodihydrofluorescein diacetate $\left(\mathrm{H}_{2} \mathrm{DCFDA}\right.$; Molecular Probes, Eugene, OR, USA) dye for $10 \mathrm{~min}, \mathrm{H}_{2} \mathrm{DCF}$ fluorescence was detected by flow cytometry (Becton Dickinson, Mountain View, CA, USA) and analyzed using the Cell Quest software. For imaging, cells were plated in a 4-well glass chamber slide, treated with $1 \mathrm{mM} \mathrm{NAC}$ and/or $50 \mu \mathrm{g} / \mathrm{mL}$ $\mathrm{PM}_{2.5}$, and analyzed for intracellular and mitochondrial ROS production after staining with $\mathrm{H}_{2}$ DCFDA and dihydrorhodamin 123 (DHR 123; Molecular Probes), respectively, for $30 \mathrm{~min}$. Images of stained cells were generated by confocal microscopy as previously described (Kim and Yoo 2016; Soeur et al. 2017). To detect ROS in zebrafish treated with NAC and/or $\mathrm{PM}_{2.5}$, they were incubated with $10 \mu \mathrm{M}$ $\mathrm{H}_{2}$ DCFDA for $30 \mathrm{~min}$ in the dark at $28.5^{\circ} \mathrm{C}$. After anesthesia with 1-phenoxy-2-propanol (1/500 dilution; Acros Organics, Morris Plains, NJ, USA), the stained zebrafish were observed under a fluorescence microscope (Zeiss AX10, Carl Zeiss, Göttingen, Germany) (Jeong et al. 2017).

\section{Hoechst 33342/propidium iodide (PI) staining}

Cells were treated with different concentrations of $\mathrm{PM}_{2.5}(25$, 50,75 , and $100 \mu \mathrm{g} / \mathrm{mL}$ ) for $24 \mathrm{~h}$ or pre-treated with $1 \mathrm{mM}$ $\mathrm{NAC}$ for $1 \mathrm{~h}$ and then treated with $50 \mu \mathrm{g} / \mathrm{mL}$ of $\mathrm{PM}_{2.5}$ for $24 \mathrm{~h}$ and then stained with DNA-specific fluorescent dyes Hoechst $33342(10 \mu \mathrm{M})$ and propidium iodide (PI; $5 \mu \mathrm{g} / \mathrm{mL}$ ) (both from Sigma-Aldrich). Cells with fragmented nuclei stained with Hoechst 33342 were considered apoptotic and those stained with PI were considered necrotic. Cell staining was visualized under a fluorescence microscope equipped with a CoolSNAP-Pro color digital camera (Media Cybernetics, Rockville, MD, USA) and the proportions of apoptotic and neurotic cell were quantified. 


\section{Trypan blue assay}

Cells were seeded in $35-\mathrm{mm}$ culture dishes at a concentration of $1.0 \times 10^{5}$ per $\mathrm{mL}$, cultured for $16 \mathrm{~h}$, and treated with different concentrations of $\mathrm{PM}_{2.5}(25,50,75$, and $100 \mu \mathrm{g} /$ $\mathrm{mL}$ ) for $24 \mathrm{~h}$. Then, $5 \mu \mathrm{L}$ of $0.1 \%$ trypan blue solution was added to $0.1 \mathrm{~mL}$ cell suspension for $5 \mathrm{~min}$ at room temperature, and the numbers of viable and dead cells were determined under a microscope using $10 \times$ magnification. Cell viability (\%) was calculated as: unstained cells/(unstained cells + stained cells) $\times 100 \%$.

\section{Detection of 8-oxoguanine}

Cellular DNA was isolated using the G-DEX ${ }^{\mathrm{TM}}$ IIc Genomic DNA Extraction Kit (iNtRON Biotechnology, Inc., Sungnam, Kyungki-Do, Republic of Korea) and quantified by spectrophotometry. The amount of 8-hydroxy-2-deoxyguanosine (8-OHdG, the deoxyriboside form of 8-oxoG) in DNA was determined using the BIOXYTECH ${ }^{\circledR} 8-\mathrm{OHdG}-$ EIA $^{\text {TM }}$ kit (OXIS Health Products, Inc., Portland, OR, USA) according to the manufacturer's instructions. The amount of 8-oxoG was also estimated by a fluorescence-binding assay: cells were fixed and permeabilized with ice-cold methanol for $15 \mathrm{~min}$ and 8-oxoG was visualized with avidin-TRITC conjugate (Sigma-Aldrich) under a confocal microscope (Piao et al. 2011).

\section{Single cell gel electrophoresis (Comet assay)}

Cell-coated slides were immersed in lysis buffer $(2.5 \mathrm{M}$ $\mathrm{NaCl}, 100 \mathrm{mM}$ Na-EDTA, $10 \mathrm{mM}$ Tris, $1 \%$ Trion X-100, and $10 \%$ DMSO, pH 10) for $1 \mathrm{~h}$ at $4{ }^{\circ} \mathrm{C}$, subjected to electrophoresis, stained with ethidium bromide, and observed under a fluorescence microscope equipped with an image analysis software (Kinetic Imaging, Komet 5.5, UK) as previously described (Park et al. 2017). The percentage of the total fluorescence in the comet tail and the length of the tail was recorded in 50 cells per slide.

\section{Lipid peroxidation assay}

Cells were stained with $5 \mu \mathrm{M}$ of a fluorescent probe diphenyl-1-pyrenylphosphine (DPPP; Molecular Probes) as described (Morita et al. 2016) and analyzed using an Olympus FV1200 laser scanning microscope equipped with the FV10-ASW viewer 4.2 software. Mouse skin tissue was analyzed by immunohistochemistry using an antibody to 4-hydroxy-2-nonenal (4-HNE) (Cosmo Bio Co., Tokyo, Japan).

\section{Protein carbonylation}

Total cellular proteins were extracted with lysis buffer and quantified by spectrophotometry, and protein carbonylation was determined using an OxiSelect ${ }^{\mathrm{TM}}$ protein carbonyl ELISA kit (Cell Biolabs, San Diego, CA, USA) according to the manufacturer's instructions. In tissues, protein carbonylation was assessed using an immunohistochemical staining kit (Cosmo Bio Co.)

\section{Western blotting}

Cell and mouse skin lysates were subjected to SDS-PAGE, and the separated proteins were transferred to membranes and incubated with primary antibodies against phosphoH2A.X (Ser139), CHOP, phospho-PERK, beclin-1, LC3B, caspase-3, and caspase-9 (Cell Signaling Technology, Beverly, MA, USA), GRP78, Bax (Santa Cruz Biotechnology, Santa Cruz, CA, USA), phospho-IRE1 (Abcam, Cambridge, MA, USA), and actin (Sigma-Aldrich) followed by the incubation with a secondary antibody (Pierce, Rockford, IL, USA). Protein bands were detected using an Amersham Enhanced Chemiluminescence Plus Western Blotting Detection system (GE Healthcare Life Sciences, Buckinghamshire, UK).

\section{ER staining}

Cells were reacted with an ER-tracker blue-white DPX dye (Molecular Probes) for 30 min, and images were taken under a confocal microscope (Li et al. 2015).

\section{Quantification of $\mathrm{Ca}^{2+}$ level}

Cells were loaded for $30 \mathrm{~min}$ with $10 \mu \mathrm{M}$ fluo-4-acetoxymethyl ester (Fluo-4-AM) or with Rhod-2 acetoxymethyl ester (Rhod-2 AM) (Molecular Probes) to detect intracellular and mitochondrial $\mathrm{Ca}^{2+}$, respectively, and fluorescence was measured by confocal microscopy (Wang et al. 2016).

\section{Mitochondrial membrane potential $\left(\Delta_{\psi \mathrm{m}}\right)$ measurement}

Mitochondrial $\Delta_{\psi}$ was analyzed by confocal microscopy after staining with $5,5^{\prime}, 6,6^{\prime}$-tetrachloro-1, $1^{\prime}, 3,3^{\prime}$ tetraethylbenzimidazolylcarbocyanine iodide (JC-1, Invitrogen, Carlsbad, CA, USA), a lipophilic cationic fluorescence dye (Yao et al. 2016).

\section{Acridine orange staining}

To analyze autophagy, cells were reacted with acridine orange (Invitrogen) for $15 \mathrm{~min}$ and fluorescence was 
measured using a fluorescence microscope (BH2-RFL-T3; Olympus, Tokyo, Japan) (Farah et al. 2016). Depending on the acidity, autophagic lysosomes appeared as orange/ red fluorescent cytoplasmic vesicles, while the nuclei were stained green.

\section{LC3 transfection and detection of punctate LC3-positive structures}

Membrane-bound microtubule-associated protein 1 light chain 3 (LC3) is present in the autophagic double-membrane structure, which is an important marker of autophagy (Fazeli and Wehman 2017). Cells were transfected with GFP-tagged LC3 using Lipofectamine reagent (Invitrogen) according to the manufacturer's instructions and GFP-LC3 fluorescence was observed under a confocal microscope.

\section{Histological analysis}

Skin pieces were fixed in $4 \%$ paraformaldehyde, embedded in paraffin, and cut into $5 \mu \mathrm{m}$ sections, which were then deparaffinized and stained with hematoxylin and eosin. The height of epidermis (from the stratum basale to the stratum corneum) was measured in ten randomly chosen fields from three representative sections per group by microscopy at $100 \times$ magnification using a digital camera. Immunohistochemistry was performed by incubating skin sections with primary anti-Bax antibody (1:400; Abcam, Cambridge, MA, USA) for $1 \mathrm{~h}$ and the reaction was visualized using an $\mathrm{ABC}$ Elite kit (Vector Labs, Burlingame, CA, USA). The sections were counterstained with hematoxylin before mounting. For the in situ detection of apoptotic cells in skin sections, the DeadEnd colorimetric TUNEL system (Promega, Wisconsin, WI, USA) was used according to the manufacturer's recommendation.

\section{Transmission electron microscopy (TEM)}

Cells and tissues were fixed, dehydrated, incubated with increasing concentrations of propylene oxide dissolved in ethanol, and infiltrated with increasing concentrations of Eponate 812 resin. Samples were baked in a $65{ }^{\circ} \mathrm{C}$ oven overnight, sectioned in an ultramicrotome, and examined by TEM using a field electron emission unit (JEM-2100F, JEOL) at the Korean Basic Science Institute (Chuncheon, Republic of Korea).

\section{Statistical analysis}

Statistical significance of the difference between groups was determined by analysis of variance and Tukey's tests using the SigmaStat version 3.5 software (Systat Software Inc., San Jose, CA, USA). All data are presented as the mean \pm standard error. $p<0.05$ was considered to indicate statistically significant difference.

\section{Results}

\section{$\mathrm{PM}_{2.5}$ induced oxidative stress both in vitro and in vivo}

To investigate the potential role of oxidative stress induced by $\mathrm{PM}_{2.5}$, we measured ROS generation and cellular damage in $\mathrm{PM}_{2.5}$-treated human keratinocytes and mouse skin. Figure 1 a shows that $\mathrm{PM}_{2.5}$ treatment promoted the production of ROS in a dose-dependent manner as evidenced by $\mathrm{H}_{2}$ DCFDA staining. Analysis of Hoechst 33342/PI staining indicated that $\mathrm{PM}_{2.5}$ at a concentration of $50 \mu \mathrm{g} / \mathrm{mL}$ induced apoptosis (Hoechst 33342-stained cells); however, at concentrations above $75 \mu \mathrm{g} / \mathrm{mL}, \mathrm{PM}_{2.5}$ induced necrosis (PI-stained cells) (Fig. 1b). We used $50 \mu \mathrm{g} / \mathrm{mL} \mathrm{PM}_{2.5}$ as the optimal concentration in further experiments. ROS generation was increased starting from $1 \mathrm{~h}$ up to $24 \mathrm{~h}$ of treatment with $50 \mu \mathrm{g} / \mathrm{mL} \mathrm{PM}_{2.5}$ (Fig. 1c). Next, we determined whether $\mathrm{PM}_{2.5}$ induced cytotoxicity via ROS generation. An antioxidant NAC was not toxic for $\mathrm{HaCaT}$ cells at concentrations up to $1 \mathrm{mM}$ (MTT test; data not shown); therefore, $1 \mathrm{mM} \mathrm{NAC}$ was used in this study. Confocal microscopy indicated that green fluorescence was increased in $\mathrm{PM}_{2.5}$-treated cells compared to control, but the effect was suppressed by $1 \mathrm{mM}$ NAC (Fig. 1d), indicating that $\mathrm{PM}_{2.5}$ stimulated ROS production in keratinocytes. Furthermore, $\mathrm{PM}_{2.5}$ induced cytotoxicity as evidenced by trypan blue exclusion; however, $1 \mathrm{mM}$ NAC reduced it (Fig. 1e), suggesting that $\mathrm{PM}_{2.5}$ caused cytotoxicity via ROS. We next evaluated the damage of intracellular macromolecules by $\mathrm{PM}_{2.5}$. The level of 8-oxoG, a hallmark of oxidative DNA damage, was measured based on 8-OHdG detection. The results indicated that $\mathrm{PM}_{2.5}$ promoted the generation of 8 -oxoG in DNA in a time-dependent manner when used at $50 \mu \mathrm{g} / \mathrm{mL}$ (Fig. 1f) and in a dose-dependent manner when administered for $8 \mathrm{~h}$ (Fig. 1g). In addition, condensed 8-oxoG staining was observed in $\mathrm{PM}_{2.5}$-treated cells, whereas $1 \mathrm{mM} \mathrm{NAC}$ reduced it (Fig. 1h). The Comet assay assessing DNA breakage indicated that $\mathrm{PM}_{2.5}$ increased the presence of cellular DNA tails by $30 \%$ compared to control; however, NAC pre-treatment reduced it to $12 \%$ (Fig. 1i). Furthermore, fluorescence intensity of DPPP oxide, an indicator of lipid peroxidation, was enhanced in $\mathrm{PM}_{2.5}$-incubated cells but significantly reduced by NAC pre-treatment (Fig. 1j). Similarly, the level of protein carbonylation, a biomarker of oxidative stress-induced protein damage, was increased in $\mathrm{PM}_{2.5}$-treated cells, whereas NAC could prevent $\mathrm{PM}_{2.5}$-induced carbonyl formation (Fig. $1 \mathrm{k}$ ). To 
a

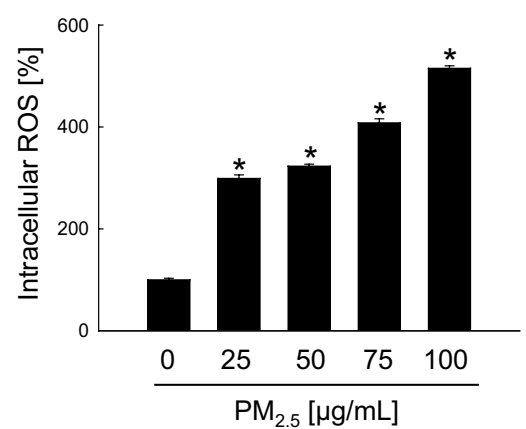

C

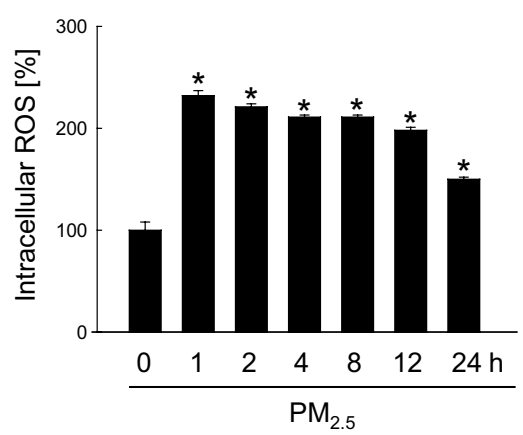

e
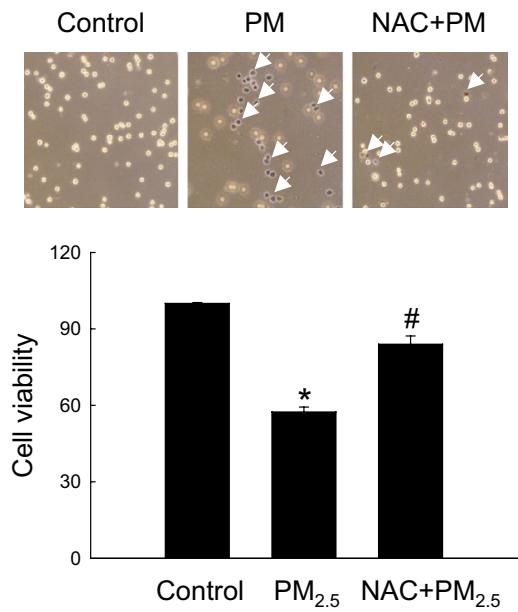

Fig. $1 \mathrm{PM}_{2.5}$ induces ROS production leading to oxidative damage. Cells were treated with $\mathrm{PM}_{2.5}$ at the indicated concentrations for $24 \mathrm{~h}$. a ROS generation was assessed by the $\mathrm{H}_{2}$ DCFDA assay. b Apoptotic and necrotic cells were detected by Hoechst 33342 and PI nuclear staining, respectively. Arrows indicate apoptotic bodies and red color indicates necrotic cells. c Cells were treated with $50 \mu \mathrm{g} / \mathrm{mL} \mathrm{PM}_{2.5}$ for the indicated times and ROS generation was assessed by the $\mathrm{H}_{2}$ DCFDA assay. Cells were pre-treated with NAC $(1 \mathrm{mM})$ for $1 \mathrm{~h}$ and then treated with $\mathrm{PM}_{2.5}(50 \mu \mathrm{g} / \mathrm{mL})$ for $24 \mathrm{~h}$. d ROS levels were assessed by confocal microscopy after $\mathrm{H}_{2}$ DCFDA staining. e Cell viability was analyzed by trypan blue exclusion. Cells were treated with $50 \mu \mathrm{g} / \mathrm{mL} \mathrm{PM}_{2.5}$ f for the indicated times or $\mathbf{g}$ with the indicated concentrations of $\mathrm{PM}_{25}$ for $8 \mathrm{~h}$ and analyzed for the generation of 8-oxoG in DNA by avidin-TRITC binding using confocal microscopy. i DNA damage was evaluated by the Comet assay; representative images show comet tails and the graph shows quantification of cel- b
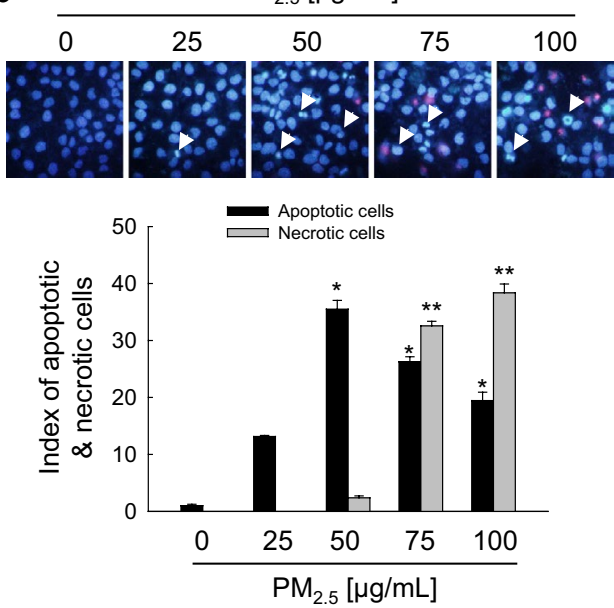

d
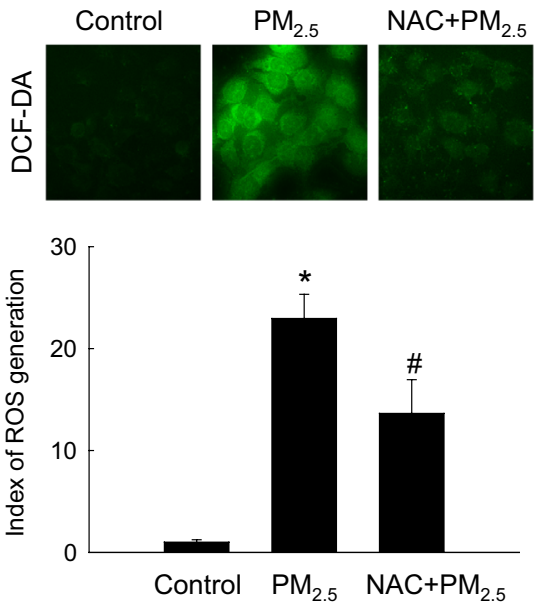

$\mathbf{f}$

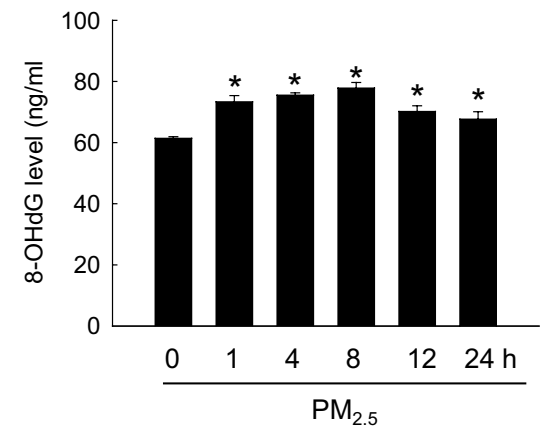

lular DNA damage. $\mathbf{j}$ Lipid peroxidation was analyzed by confocal microscopy after DPPP staining. k Protein oxidation was assayed by measuring carbonyl formation. I Zebrafish was pre-treated or not with NAC and then treated with $\mathrm{PM}_{2.5}(50 \mu \mathrm{g} / \mathrm{mL})$ for $24 \mathrm{~h}$, and analyzed for ROS production by $\mathrm{H}_{2}$ DCFDA staining; zebrafish treated with $\mathrm{H}_{2} \mathrm{O}_{2}$ was used as a positive control. Mouse dorsal skin was treated with $\mathrm{PM}_{2.5}(100 \mu \mathrm{g} / \mathrm{mL})$ for 7 days. m Tissue lysates were analyzed for H2A.X expression by immunoblotting; actin was used as loading control. n Immunohistochemistry of mouse tissue to analyze 4-HNE levels as a marker of lipid peroxidation; signals were detected in a peroxidase reaction (brown), and slides were counterstained with hematoxylin; magnification: $\times 400$. o Protein carbonylation in mouse tissue was assessed using an immunohistochemical staining kit for protein carbonyls. $* p<0.05$ compared to control groups and ${ }^{\#} p<0.05$ compared to $\mathrm{PM}_{2.5}$-treated groups. (Color figure online) 
g

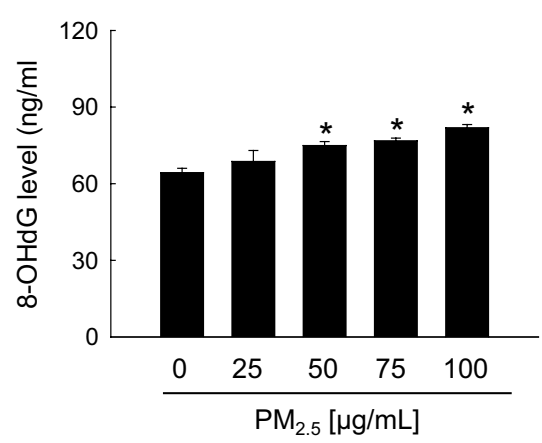

i
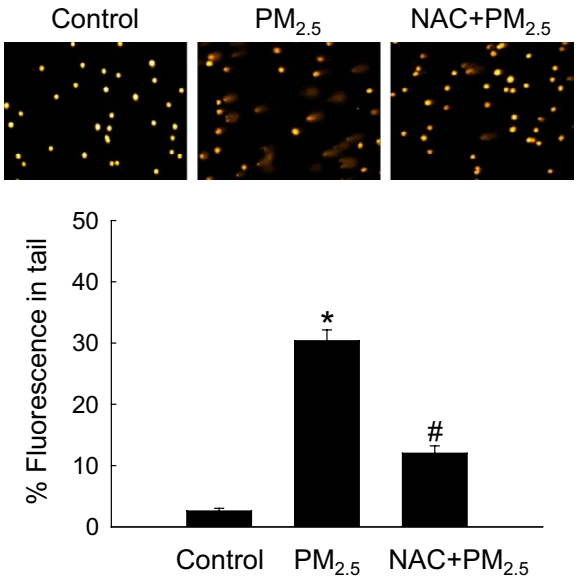

k

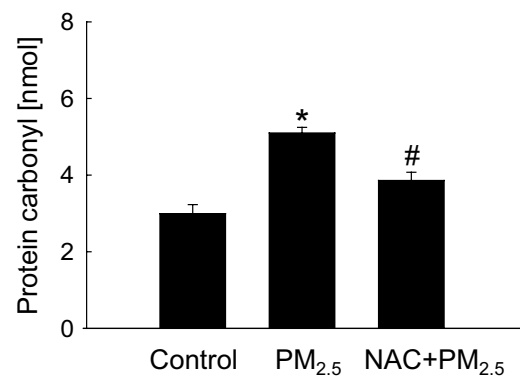

h
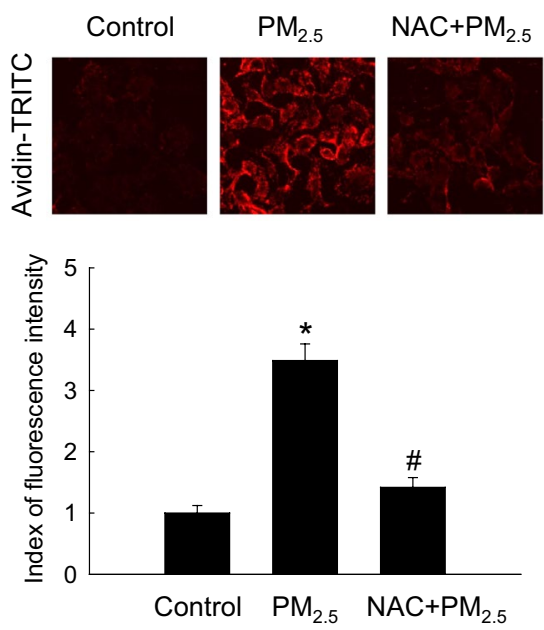

j
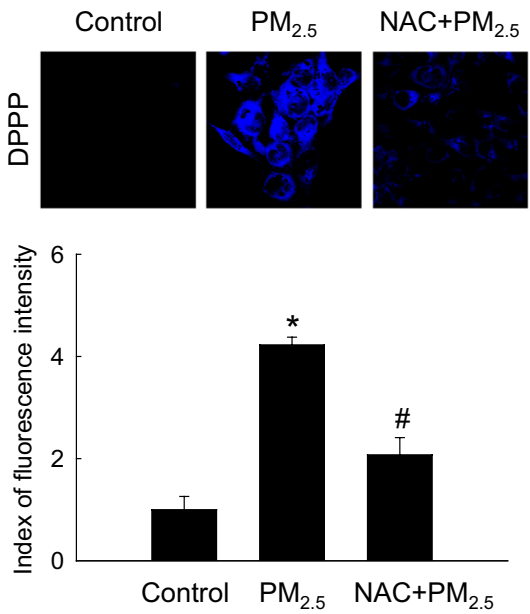

Fig. 1 (continued)

validate these results in vivo, we used a zebrafish model. As shown in Fig. 11, $\mathrm{PM}_{2.5}$ treatment also upregulated ROS production in zebrafish, which was attenuated by NAC. Finally, the results were confirmed in a mouse model, which showed that $\mathrm{PM}_{2.5}$ treatment induced DNA damage as indicated by the expression of phosphorylated histone H2A.X (Fig. 1m), and stimulated lipid peroxidation (Fig. 1n) and protein carbonylation (Fig. 1o) in mouse skin. Overall, these findings show that $\mathrm{PM}_{2.5}$ induced oxidative stress by enhancing ROS production, which resulted in the damage of cellular components.

\section{$\mathrm{PM}_{2.5}$-induced oxidative damage caused ER stress}

We next investigated whether $\mathrm{PM}_{2.5}$ oxidative effects resulted in ER stress. $\mathrm{PM}_{2.5}$-treated cells were stained bright blue by the ER-Tracker Blue-White DPX, indicating the induction of ER stress which was attenuated by NAC (Fig. 2a), suggesting that $\mathrm{PM}_{2.5}$ promoted ER stress through ROS generation. ER is a major intracellular $\mathrm{Ca}^{2+}$ reservoir, and disruption of $\mathrm{Ca}^{2+}$ homeostasis activates ER stress (Jakobsen et al. 2008; $\mathrm{Xu}$ et al. 2005). Confocal microscopy analysis revealed higher intensity of $\mathrm{Ca}^{2+}$ fluorescence in $\mathrm{PM}_{2.5}$-treated cells compared 


\section{I}
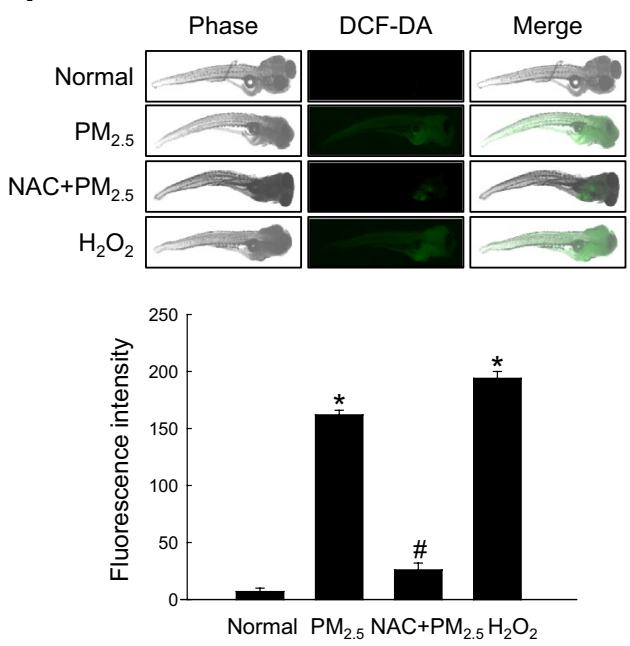

n

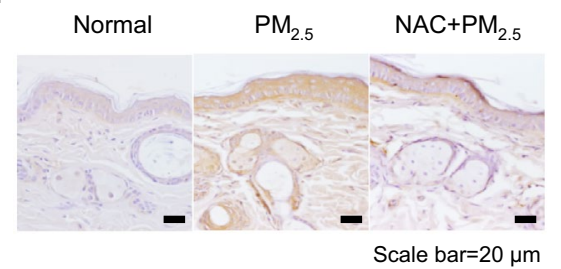

m
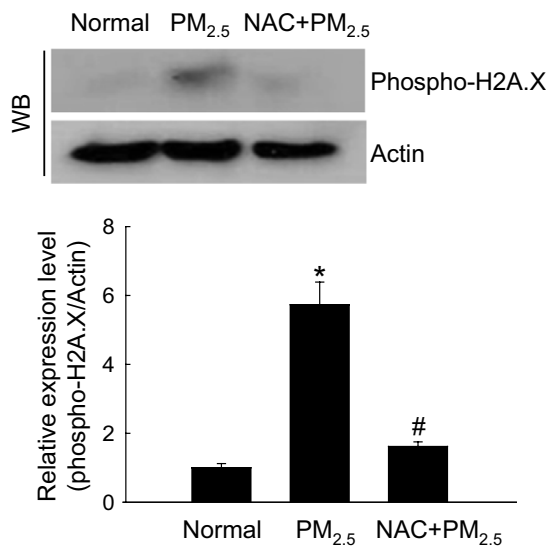

o

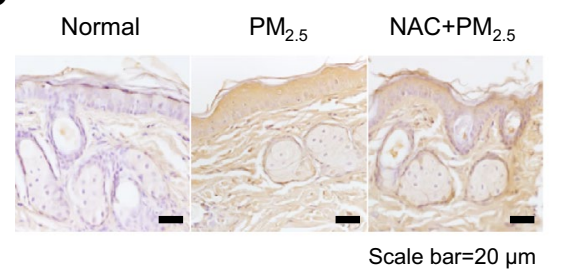

Fig. 1 (continued)

with control, but the effect was reduced by NAC (Fig. 2b). ER stress promotes the expression of C/EBP homologous protein (CHOP), which mediates apoptosis (Nishitoh 2012), and of the ER chaperone and signaling regulator GRP78, which activates protein kinase R-like ER kinase (PERK) through phosphorylation. In turn, phospho-PERK causes inhibition of translation and protein synthesis observed after ER stress (Bertolotti et al. 2000). As shown in Fig. 2c, $\mathrm{PM}_{2.5}$ induced the expression of ER stress-related proteins, including CHOP, GRP78, phospho-PERK, and phospho-serine/threonine-protein kinase/ endoribonuclease inositol-requiring enzyme 1 (IRE1) in a time-dependent manner. To confirm these results, we examined the induction of ER stress markers in mice treated with $\mathrm{PM}_{2.5}$ and found that the expression of GRP78 and CHOP was significantly increased in $\mathrm{PM}_{2.5}$-treated skin compared with control; however, NAC reversed the effect (Fig. 2d). These observations were consistent with those in vitro, suggesting that $\mathrm{PM}_{2.5}$-induced ER stress may be associated with oxidative stress.

\section{$\mathrm{PM}_{2.5}$-induced oxidative stress promoted mitochondrial damage}

Confocal microscopy analysis showed that, in cultured human keratinocytes, ROS generation and $\mathrm{Ca}^{2+}$ overload in mitochondria were enhanced by $\mathrm{PM}_{2.5}$ treatment but reduced by NAC (Fig. 3a, b). Mitochondrial membrane permeability is associated with apoptosis through the release of cytochrome $c$ and caspase activation (Chaudhary et al. 2016). A membrane-permeant dye JC-1 is widely used in apoptosis studies to monitor the status of mitochondria where JC-1 accumulates in a potential-dependent manner as indicated by a fluorescence emission shift from green $(\sim 529 \mathrm{~nm})$ to red $(\sim 590 \mathrm{~nm})$. Accordingly, mitochondrial polarization (healthy state) or depolarization (damaged state) can be revealed by an increase or decrease, respectively, in the red/green fluorescence intensity ratio (Lee et al. 2017). Confocal microscopy images showed that in control cells, mitochondria exhibited strong red JC-1 fluorescence indicative of $\Delta_{\psi \mathrm{m}}$ polarization, which was reduced in $\mathrm{PM}_{2.5}$-treated cells where green fluorescence indicative of $\Delta_{\psi \mathrm{m}}$ depolarization was increased; however, the effect was suppressed by NAC (Fig. 3c).

It is known that proteins of the $\mathrm{Bcl}-2$ family regulate apoptosis by controlling mitochondrial permeability. Therefore, we next examined whether $\mathrm{PM}_{2.5}$ affected the expression of Bax, a pro-apoptotic member of the Bcl-2 family. The results indicated that $\mathrm{PM}_{2.5}$ increased Bax levels in cultured human keratinocytes (Fig. 3d) as well as in mouse skin (Fig. 3e, f); however, NAC pre-treatment prevented 
Fig. $2 \mathrm{PM}_{2.5}$ induces ER stress via ROS generation. a, b Cells were pre-treated or not with NAC $(1 \mathrm{mM})$ for $1 \mathrm{~h}$ and then with $\mathrm{PM}_{2.5}(50 \mu \mathrm{g} / \mathrm{mL})$ for $24 \mathrm{~h}$ and analyzed by confocal microscopy for ER stress using a ER-Tracker Blue-White DPX staining and for intracellular $\mathrm{Ca}^{2+}$ levels using b Fluo-4-AM staining. Representative confocal images are shown. Lysates of $\mathbf{c}$ cells and $\mathbf{d}$ mouse skin tissue were analyzed for the expression of CHOP, GRP78, phospho-PERK, and phosphoIRE1 by western blotting. Actin was used as loading control. $* p<0.05$ compared to control groups and ${ }^{\#} p<0.05$ compared to $\mathrm{PM}_{2.5}$-treated groups a
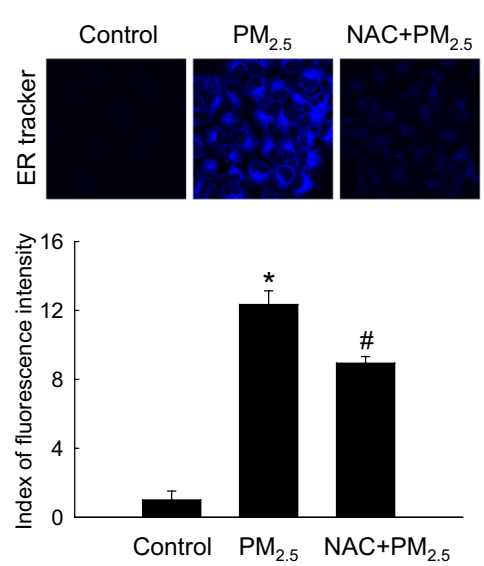

b
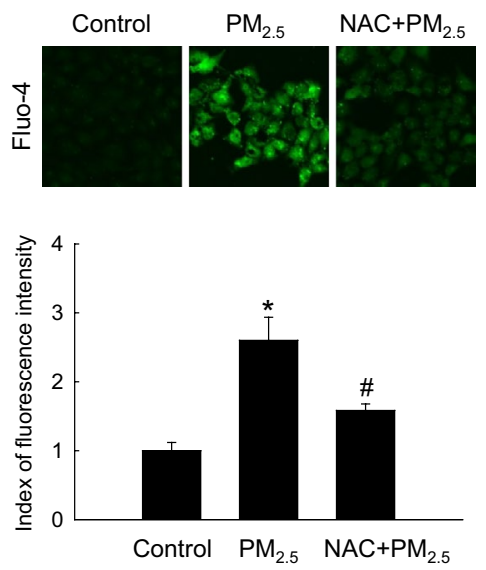

d
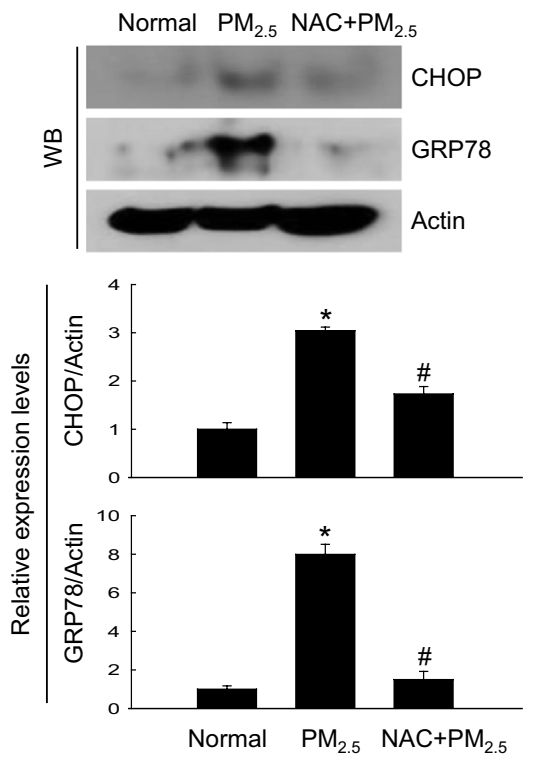

C
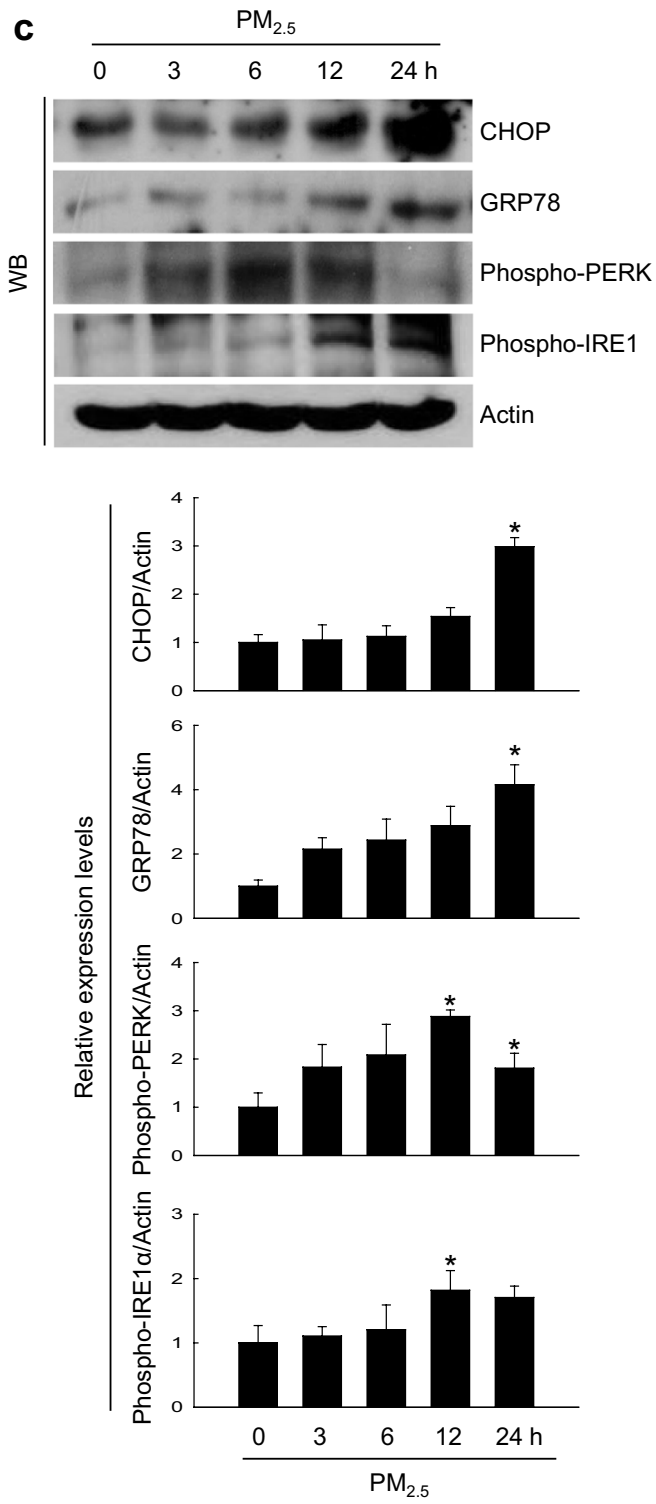

$\mathrm{PM}_{2.5}$-induced upregulation of Bax expression (Fig. 3e, $\mathrm{f}$ ). Cumulatively, these data indicate that $\mathrm{PM}_{2.5}$ increased oxidative stress in mitochondria by stimulating ROS production, which resulted in mitochondrial damage.

\section{$\mathrm{PM}_{2.5}$-induced oxidative stress caused autophagy}

We next determined whether $\mathrm{PM}_{2.5}$-induced oxidative stress could promote autophagy. In cultured keratinocytes, 
Fig. $3 \mathrm{PM}_{2.5}$ induces mitochondrial damage via ROS generation. Cells were pre-treated or not with NAC ( $1 \mathrm{mM})$ for $1 \mathrm{~h}$ and then with $\mathrm{PM}_{2.5}(50 \mu \mathrm{g} /$ $\mathrm{mL}$ ) for $24 \mathrm{~h}$ and analyzed by confocal microscopy to assess a mitochondrial ROS (DHR123 staining), $\mathbf{b}$ mitochondrial $\mathrm{Ca}^{2+}$ levels (Rhod-2 AM staining), and $\mathbf{c} \Delta_{\psi \mathrm{m}}$ (JC-1 staining). Lysates of $\mathbf{d}$ cells and $\mathbf{e}$ mouse skin tissue were analyzed for the expression of Bax protein by western blotting. f Mouse skin tissue was analyzed for Bax expression by immunohistochemistry. Nuclei were stained with hematoxylin; arrows indicate Bax. ${ }^{*} p<0.05$ compared to control groups and ${ }^{\#} p<0.05$ compared to $\mathrm{PM}_{2.5}$-treated groups a
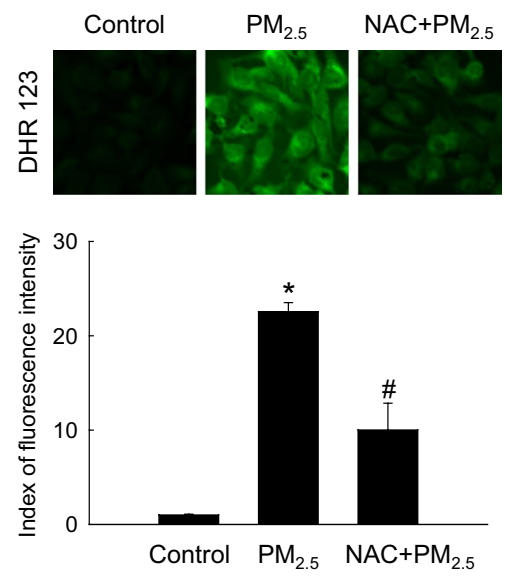

C
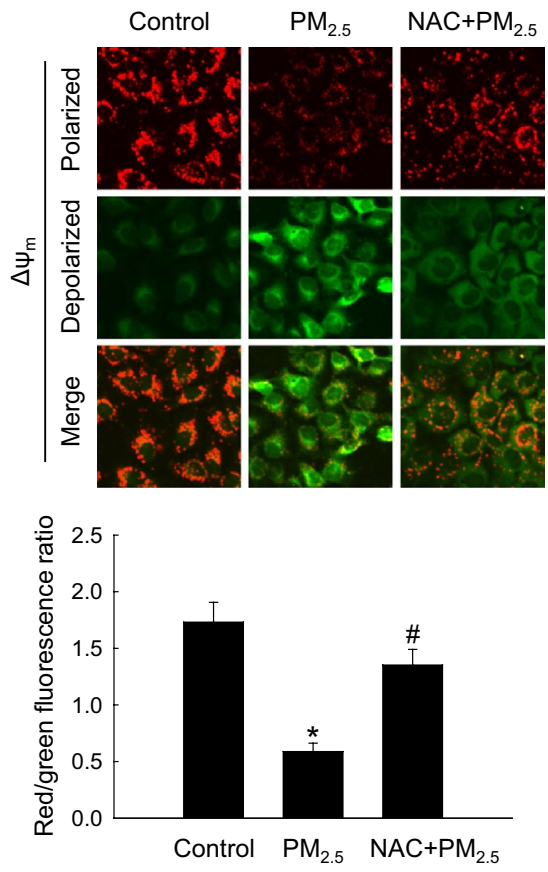

e
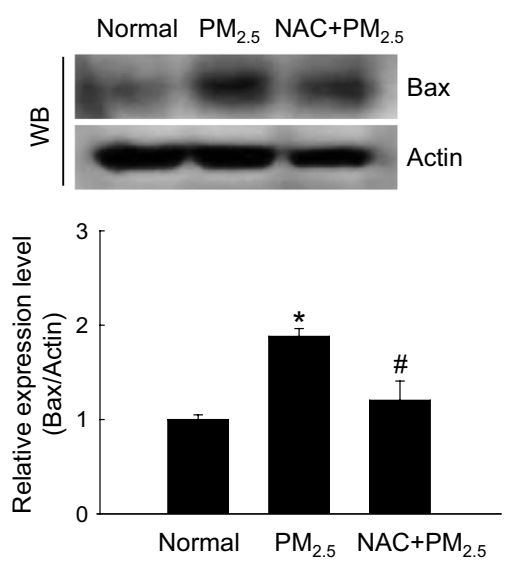
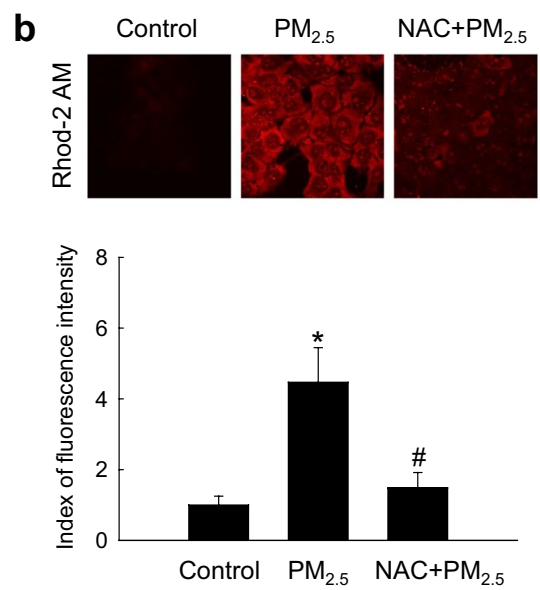

d
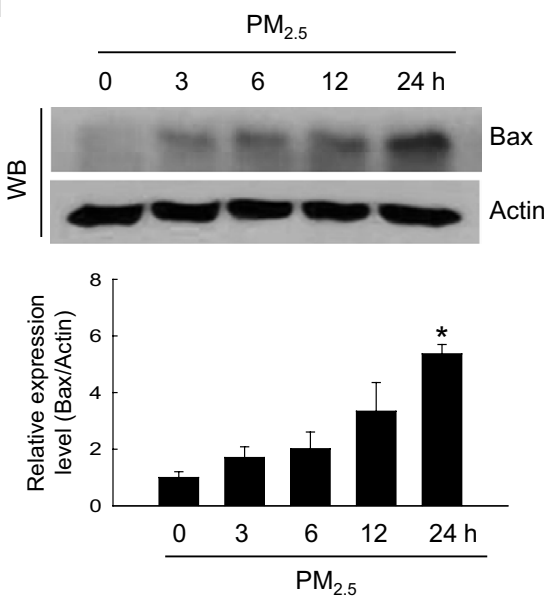

f

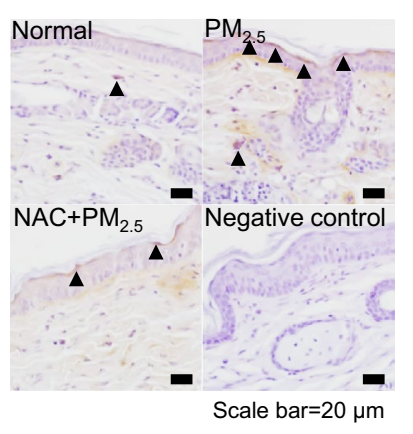


$\mathrm{PM}_{2.5}$ triggered accumulation of intracellular vacuoles indicative of autophagy, as evidenced by staining with a lysosome marker dye acridine orange (Fig. 4a). The two distinct steps of autophagy, autophagosome formation and autolysosome formation, can be discerned by the presence of LC3-phospholipid conjugates (Tanida et al. 2005). $\mathrm{PM}_{2.5}$-treated GFP-LC3-transfected cells had increased levels of GFP-LC3-positive puncta (Fig. 4b). In addition, $\mathrm{PM}_{2.5}$ upregulated the expression of beclin-1, the protein initiating autophagosome formation during autophagy, and LC3B-II, the processed form of LC3, in a time-dependent manner (Fig. 4c). These in vitro results were confirmed in $\mathrm{PM}_{2.5}$-treated mouse skin (Fig. 4d). However, the effects of $\mathrm{PM}_{2.5}$ both in cultured cell and animals were reversed by NAC (Fig. 4a, b, d), suggesting that $\mathrm{PM}_{2.5}$ increased autophagy through oxidative stress.

\section{$\mathrm{PM}_{2.5}$-induced oxidative stress promoted apoptotic cell death}

$\mathrm{PM}_{2.5}$ induced apoptosis both in cultured cells and mouse skin tissues, as shown by the formation of apoptotic bodies and DNA fragmentation revealed by Hoechst 33342 staining and TUNEL assay, respectively; however, NAC pre-treatment diminished the effects (Fig. 5a, b). Another evidence that $\mathrm{PM}_{2.5}$ promoted apoptosis was time-dependent increase in the expression of cleaved caspase- 9 and caspase- 3 (Fig. 5c), which indicated caspase activation in response to mitochondrial membrane disruption. Similar results were obtained for the mouse skin, where cleaved forms of caspase- 3 and caspase- 9 were upregulated in response to $\mathrm{PM}_{2.5}$ treatment; however, the effect was attenuated by NAC (Fig. 5d), suggesting that $\mathrm{PM}_{2.5}$ induced apoptosis via oxidative stress.

\section{$\mathrm{PM}_{2.5}$ internalization damaged the ultrastructure of mouse skin tissue}

TEM analysis revealed $\mathrm{PM}_{2.5}$ internalization in $\mathrm{HaCaT}$ cells after $24 \mathrm{~h}$ of exposure to $50 \mu \mathrm{g} / \mathrm{mL} \mathrm{PM}_{2.5}$ (Fig. 6a2). In addition, to evaluate organelle ultrastructure in skin cells following $\mathrm{PM}_{2.5}$ exposure, we performed TEM analysis of mouse skin tissue after treatment with $100 \mu \mathrm{g} / \mathrm{mL}$ $\mathrm{PM}_{2.5}$. Compared to normal mice (Fig. 6b-1), skin tissue
Fig. $4 \quad \mathrm{PM}_{2.5}$ induces autophagy via ROS generation. Cells were pre-treated or not with $\mathrm{NAC}(1 \mathrm{mM})$ for $1 \mathrm{~h}$, treated with $\mathrm{PM}_{2.5}(50 \mu \mathrm{g} / \mathrm{mL})$ for $24 \mathrm{~h}$. a Cells were stained with acridine orange and analyzed for autophagy by fluorescence microscopy. b Cells were transfected with the GFPLC3 expression construct and observed under a fluorescence microscope. Lysates extracted from $\mathbf{c}$ cells and $\mathbf{d}$ mouse skin tissue were analyzed for the expression of beclin- 1 and LC3B-II proteins by western blotting; actin was used as loading control. $* p<0.05$ compared to control groups and ${ }^{\#} p<0.05$ compared to $\mathrm{PM}_{2.5}$-treated groups. (Color figure online) a

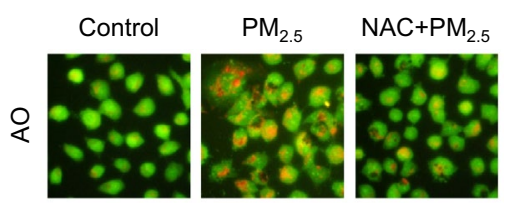

C
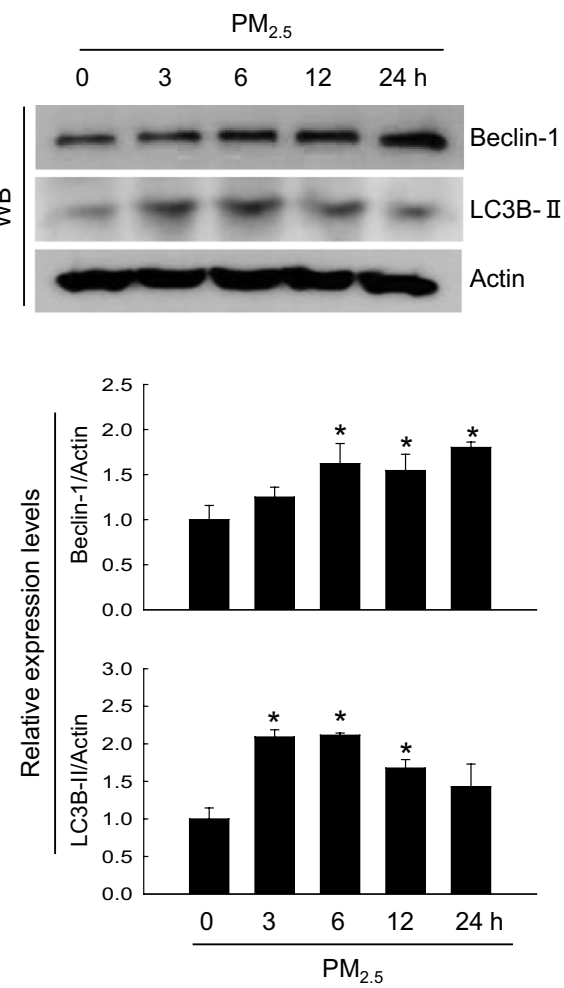

b

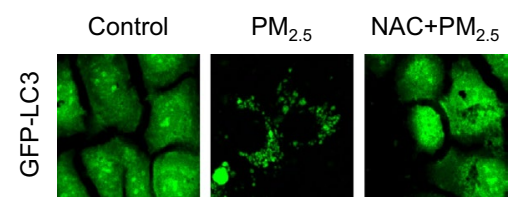

d
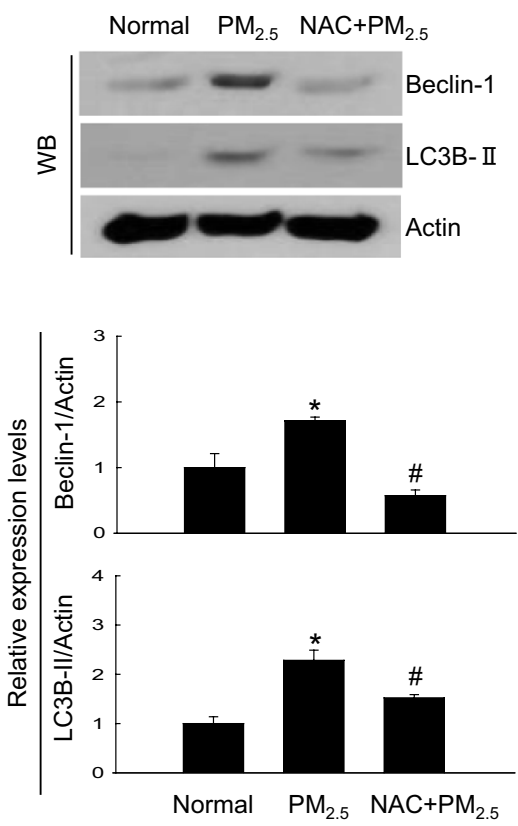
a
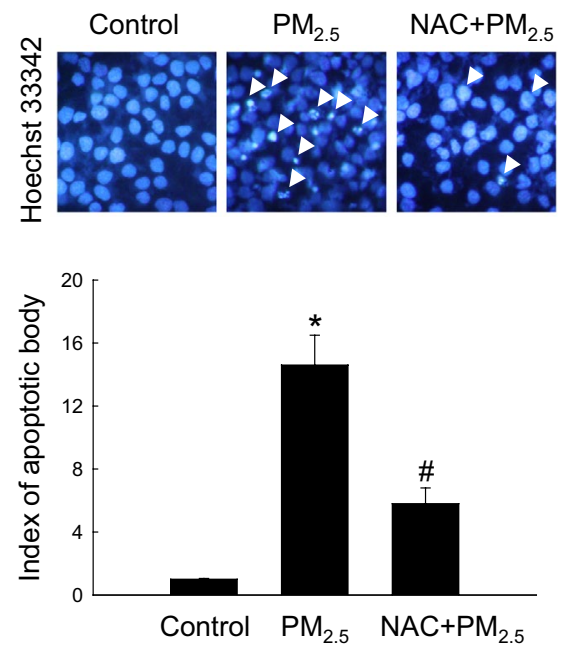

C
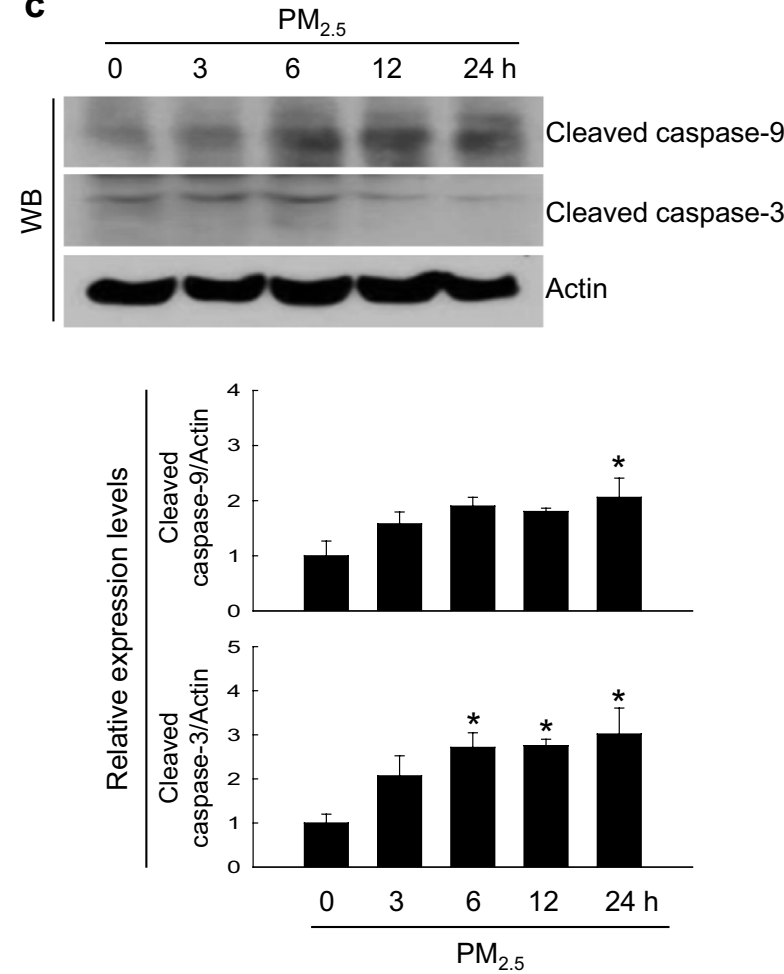

Fig. $5 \mathrm{PM}_{2.5}$ induces apoptosis via ROS generation. a Cells were pretreated or not with NAC $(1 \mathrm{mM})$ for $1 \mathrm{~h}$, treated with $\mathrm{PM}_{2.5}(50 \mu \mathrm{g} /$ $\mathrm{mL}$ ) for $24 \mathrm{~h}$, and analyzed for apoptotic body formation after Hoechst 33342 staining; apoptotic bodies are indicated by arrows. b Mouse skin treated with NAC and $\mathrm{PM}_{2.5}(100 \mu \mathrm{g} / \mathrm{mL})$ for 7 days was

of $\mathrm{PM}_{2.5}$-treated mice showed increased swelling of mitochondria (Fig. 6b-2) and ER (Fig. 6b-3), and autophagosome formation (Fig. 6b-4), indicating that $\mathrm{PM}_{2.5}$ disrupted intracellular network in the skin. b

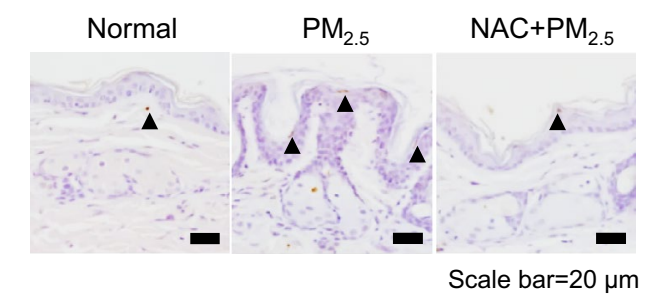

d
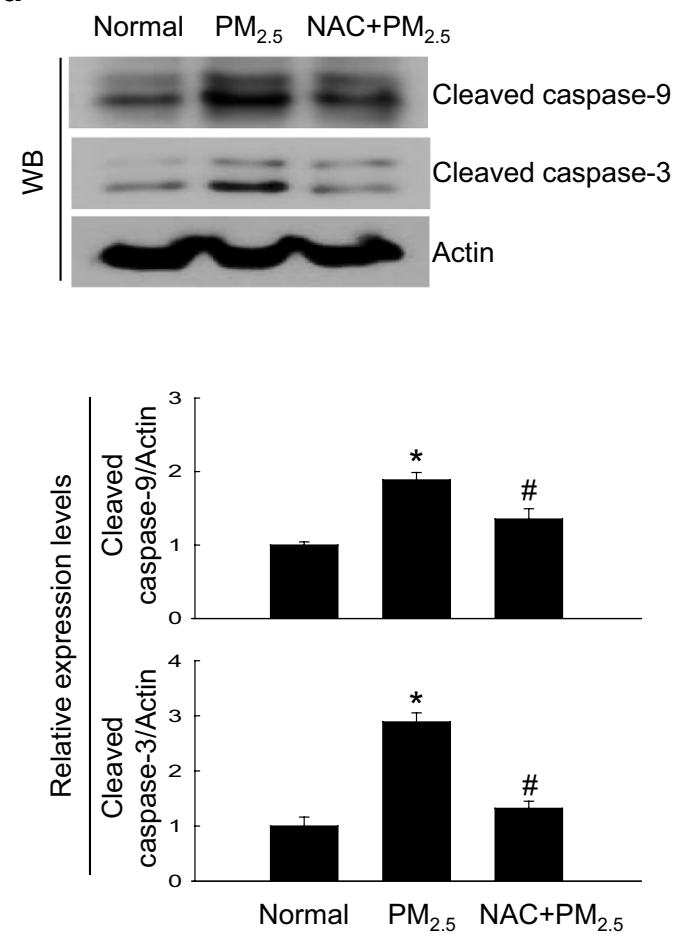

analyzed for apoptosis by TUNEL staining; TUNEL-positive cells are indicated by arrows. Lysates extracted from $\mathbf{c}$ cells and $\mathbf{d}$ mouse skin tissue were analyzed for the expression of caspase- 3 and caspase- 9 by western blotting. ${ }^{*} p<0.05$ compared to control groups and ${ }^{\#} p<0.05$ compared to $\mathrm{PM}_{2.5}$-treated groups

\section{Discussion}

According to the Air Korea site of Korea Environment Corporation $(2015,2016,2017)$ of the National Environmental Research Institute of the Republic of Korea, the average 


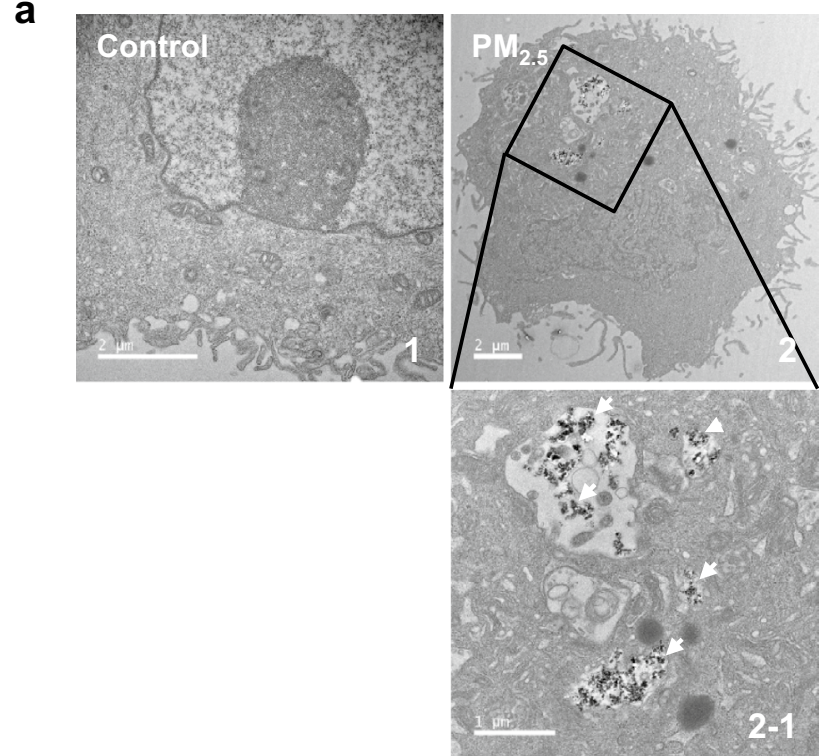

Scale bar: 1 and $2=2 \mu \mathrm{m}, 2-1=1 \mu \mathrm{m}$

b
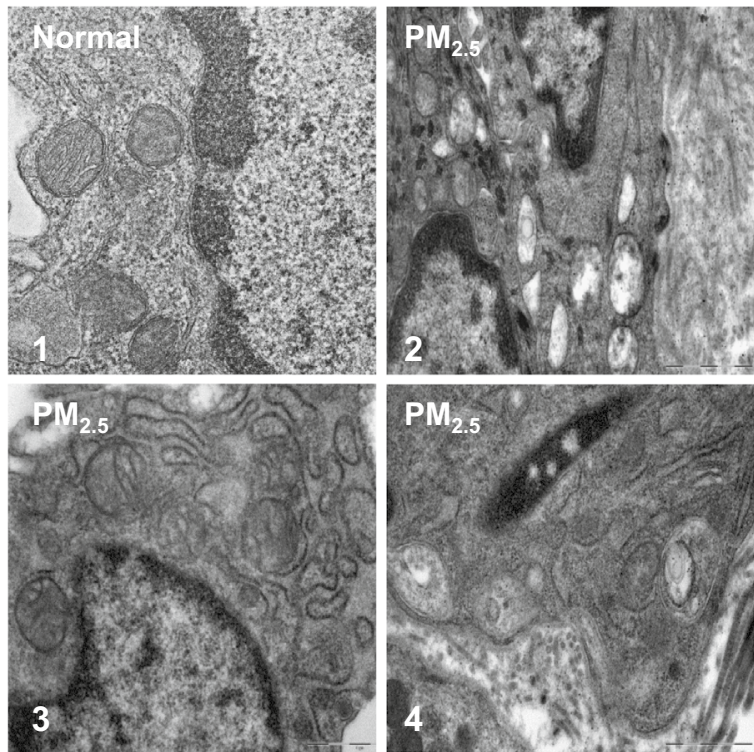

Scale bar: 1 and $3=500 \mathrm{~nm}, 2$ and $4=2 \mu \mathrm{m}$

Fig. 6 TEM analysis of HaCaT cell and mouse skin after $\mathrm{PM}_{2.5}$ treatment. a Cells were treated with $50 \mu \mathrm{g} / \mathrm{mL} \mathrm{PM}_{2.5}$ for $24 \mathrm{~h}$ and analyzed for $\mathrm{PM}_{2.5}$ internalization (white arrow); 1 control, 2 internalized $\mathrm{PM}_{2.5}$. Scale bars: 1 and 2, $2 \mu \mathrm{m} ; \mathbf{2}-\mathbf{1}, 1 \mu \mathrm{m}$. b Mouse skin treated or not with $100 \mu \mathrm{g} / \mathrm{mL} \mathrm{PM}_{2.5}$ for 7 days. Compared to $\mathbf{1}$ normal untreated skin tissue, $\mathbf{P M}_{2.5}$-treated skin showed swelling of $\mathbf{2}$ mitochondria and $\mathbf{3} \mathrm{ER}$, and the presence of $\mathbf{4}$ autophagosomes. Scale bars, $\mathbf{1}$ and $\mathbf{3}, 500 \mathrm{~nm} ; \mathbf{2}$ and $\mathbf{4}, 2 \mu \mathrm{m}$

concentrations of $\mathrm{PM}_{2.5}$ in the air of seven major Korean cities from January to March were 31,28 , and $29 \mu \mathrm{g} / \mathrm{m}^{3}$ in 2015, 2016, and 2017, respectively, exceeding the national environmental standard of $25 \mu \mathrm{g} / \mathrm{m}^{3}$.
Skin keratinocytes present the first barrier for environmental pollutants, and it was shown that PM exposure could upregulate pro-inflammatory mediators and AhR expression, leading to increased ROS generation in keratinocytes (Choi et al. 2011). Wei et al. (2017) demonstrated that organic extracts containing PAHs with $\mathrm{PM}_{2.5}$ induced stronger oxidative stress compared to those without $\mathrm{PM}_{2.5}$. It was also shown that $\mathrm{PM}_{2.5}$ may penetrate the skin and have harmful effects on viable skin cells, including keratinocytes (Krutmann et al. 2014; Li et al. 2017). A recent study demonstrated that $\mathrm{PM}_{2.5}$ could increase ROS production and inhibit the intracellular antioxidant system, which resulted in morphological changes and decreased viability of keratinocytes (Hu et al. 2017). Therefore, in the current study, we investigated the effects of oxidative stress induced by $\mathrm{PM}_{2.5}$ on keratinocytes in vitro and in vivo. Our data indicate that $\mathrm{PM}_{2.5}$ treatment promoted ROS generation (Fig. 1a, c) and caused structural damage, including DNA oxidation, lipid peroxidation, and protein carbonylation (Fig. 1f-k). Recent studies have shown that ER stress is associated with oxidative stress and that ROS may act as messengers between these processes (Cao and Kaufman 2014; Laing et al. 2010). Excessive $\mathrm{ER} \mathrm{Ca}^{2+}$ release and mitochondrial $\mathrm{Ca}^{2+}$ overload further amplify oxidative stress (Ly et al. 2017). Therefore, we hypothesized that ROS overproduction induced by $\mathrm{PM}_{2.5}$ affected the ER which plays an important role in cellular quality control and sensitivity to oxidative stress. Abnormal ER stress is associated with autophagy-induced protein degradation and activation of cytotoxic processes such as apoptosis (Schrock et al. 2013), which may be a key mechanism underlying $\mathrm{PM}_{2.5}$ toxicity. GRP78 is a major ER chaperone critical for protein quality control in the ER and activation of ER transmembrane signaling molecules (Wang et al. 2009). GRP78 interacts with misfolded proteins and promotes their refolding, thereby playing an important role in regulating three ER transmembrane proteins: PERK, IRE- $1 \alpha$, and activating transcription factor 6 (ATF6) (Mei et al. 2013). Our data show that $\mathrm{PM}_{2.5}$ could induce IRE-1 phosphorylation, upregulate GRP78 and CHOP expression, and activate the ER stress pathway in human keratinocytes (Fig. 2c, d). Furthermore, ER stress is known to be strongly associated with the disruption of cellular $\mathrm{Ca}^{2+}$ homeostasis, and our results revealed that $\mathrm{PM}_{2.5}$-induced ER stress increased intracellular $\mathrm{Ca}^{2+}$ levels, which was inhibited by NAC (Fig. 2b).

Mitochondria are considered the main source of intracellular ROS and mitochondrial dysfunction plays an important role in the pathogenesis and/or progression of various diseases. Our results demonstrate that $\mathrm{PM}_{2.5}$ induced structural alterations of mitochondria, including swelling, which can deregulate the functional activity of the mitochondrial respiratory chain and the production of ROS, and lead to mitochondrial damage, suggesting that 
Fig. $7 \mathrm{PM}_{2.5}$ causes skin injury by increasing apoptosis through oxidative stress and destruction of cellular organelles. $\mathrm{PM}_{2.5}$-induced ROS generation promotes ER stress, mitochondrial dysfunction, and autophagy, leading to apoptotic cell death and skin damage

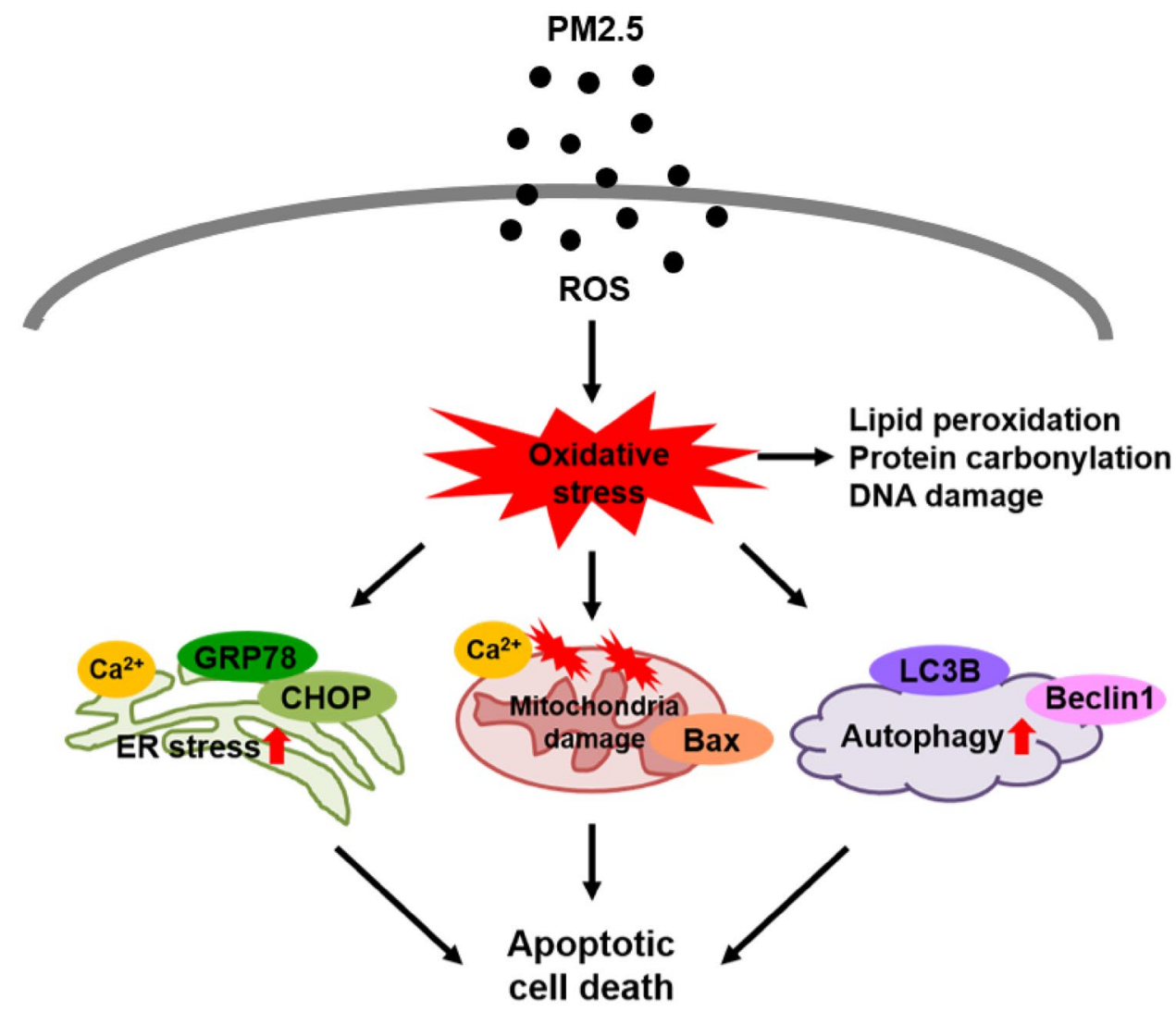

$\mathrm{PM}_{2.5}$ exposure promotes oxidative stress through destruction of mitochondria.

Autophagy is a regulated process of degradation and recycling of dysfunctional organelles and proteins, which are sequestered into autophagosomes that subsequently fuse with lysosomes where the cargo is degraded by lysosomal hydrolases (Ryter et al. 2013); however, excessive autophagy can directly cause cell death (Fulda and Kögel 2015). It has been reported that $\mathrm{PM}_{2.5}$-induced oxidative stress could trigger autophagy in various cell types (Deng et al. 2013, Su et al. 2017; Zhou et al. 2017). Consistent with these findings, we observed stimulation of autophagy in $\mathrm{PM}_{2.5}$-treated HaCaT keratinocytes in vitro and mouse keratinocytes in vivo.

In conclusion, our study shows that $\mathrm{PM}_{2.5}$ causes skin damage through induction of oxidative stress, which results in the destruction of complex macromolecules and cellular organelles, including the ER, mitochondria, and lysosomes, and promotes apoptotic cell death (Fig. 7). Thus, our results contribute to understanding of the mechanisms underlying $\mathrm{PM}_{2.5}$-induced adverse effects on the skin.

Acknowledgements This work was supported by grant from the Basic Research Laboratory Program (NRF-2017R1A4A1014512) by the
National Research Foundation of Korea (NRF) Grant funded by the Korea government (MSIP).

\section{Compliance with ethical standards}

Conflict of interest The authors declare no conflicts of interest.

Open Access This article is distributed under the terms of the Creative Commons Attribution 4.0 International License (http://creativeco mmons.org/licenses/by/4.0/), which permits unrestricted use, distribution, and reproduction in any medium, provided you give appropriate credit to the original author(s) and the source, provide a link to the Creative Commons license, and indicate if changes were made.

\section{References}

Air Korea site of Korea Environment Corporation (2015) Atmospheric Environment Statistical Yearbook, Chap 2.2, Korea. http://www. airkorea.or.kr/detailViewDown. Accessed 30 Oct 2017

Air Korea site of Korea Environment Corporation (2016) Atmospheric Environment Statistical Yearbook, Chap 2.2, Korea. http://www. airkorea.or.kr/detailViewDown. Accessed 30 Oct 2017

Air Korea site of Korea Environment Corporation (2017) Atmospheric Environment Statistical Yearbook, Chap 3.1, Korea. http://www. airkorea.or.kr/detailViewDown. Accessed 30 Oct 2017

Bertolotti A, Zhang Y, Hendershot LM, Harding HP, Ron D (2000) Dynamic interaction of $\mathrm{BiP}$ and ER stress transducers in the 
unfolded-protein response. Nat Cell Biol 2:326-332. https://doi. org/10.1038/35014014

Cao SS, Kaufman RJ (2014) Endoplasmic reticulum stress and oxidative stress in cell fate decision and human disease. Antioxid Redox Signal 21:396-413. https://doi.org/10.1089/ars.2014.5851

Chaudhary AK, Yadav N, Bhat TA, O'Malley J, Kumar S, Chandra D (2016) A potential role of X-linked inhibitor of apoptosis protein in mitochondrial membrane permeabilization and its implication in cancer therapy. Drug Discov Today 21:38-47. https://doi. org/10.1016/j.drudis.2015.07.014

Choi H, Shin DW, Kim W, Doh SJ, Lee SH, Noh M (2011) Asian dust storm particles induce a broad toxicological transcriptional program in human epidermal keratinocytes. Toxicol Lett 200:92-99. https://doi.org/10.1016/j.toxlet.2010.10.019

Costa C, Catania S, De Pasquale R, Stancanelli R, Scribano GM, Melchini A (2010) Exposure of human skin to benzo[a]pyrene: role of CYP1A1 and aryl hydrocarbon receptor in oxidative stress generation. Toxicology 271:83-86. https://doi.org/10.1016/j. tox.2010.02.014

Deng X, Zhang F, Rui W, Long F, Wang L, Feng Z, Chen D, Ding W (2013) PM2.5-induced oxidative stress triggers autophagy in human lung epithelial A549 cells. Toxicol In Vitro 27:1762-1770. https://doi.org/10.1016/j.tiv.2013.05.004

Du Y, Xu X, Chu M, Guo Y, Wang J (2016) Air particulate matter and cardiovascular disease: the epidemiological, biomedical and clinical evidence. J Thorac Dis 8:E8-E19. https://doi.org/10.3978/j. issn.2072-1439.2015.11.37

Farah MA, Ali MA, Chen SM, Li Y, Al-Hemaid FM, Abou-Tarboush FM, Al-Anazi KM, Lee J (2016) Silver nanoparticles synthesized from Adenium obesum leaf extract induced DNA damage, apoptosis and autophagy via generation of reactive oxygen species. Colloids Surf B Biointerfaces 141:158-169. https://doi.org/10.1016/j. colsurfb.2016.01.027

Fazeli G, Wehman AM (2017) Safely removing cell debris with LC3associated phagocytosis. Biol Cell 109:355-363. https://doi. org/10.1111/boc. 201700028

Fritsche E, Schäfer C, Calles C, Bernsmann T, Bernshausen T, Wurm M, Hübenthal U, Cline JE, Hajimiragha H, Schroeder P, Klotz LO, Rannug A, Fürst P, Hanenberg H, Abel J, Krutmann J (2007) Lightening up the UV response by identification of the arylhydrocarbon receptor as a cytoplasmatic target for ultraviolet B radiation. Proc Natl Acad Sci USA 104:8851-8856. https://doi. org/10.1073/pnas.0701764104

Fulda S, Kögel D (2015) Cell death by autophagy: emerging molecular mechanisms and implications for cancer therapy. Oncogene 34:5105-5113. https://doi.org/10.1038/onc.2014.458

Gualtieri M, Longhin E, Mattioli M, Mantecca P, Tinaglia V, Mangano E, Proverbio MC, Bestetti G, Camatini M, Battaglia C (2012) Gene expression profiling of A549 cells exposed to Milan PM2.5. Toxicol Lett 209:136-145. https://doi.org/10.1016/j.toxle t.2011.11.015

Guo Z, Hong Z, Dong W, Deng C, Zhao R, Xu J, Zhuang G, Zhang R (2017) PM2.5-induced oxidative stress and mitochondrial damage in the nasal mucosa of rats. Int J Environ Res Public Health 14:E134. https://doi.org/10.3390/ijerph14020134

Han X, Liang WL, Zhang Y, Sun LD, Liang WY (2016) Effect of atmospheric fine particles on epidermal growth factor receptor mRNA expression in mouse skin tissue. Genet Mol Res. https:// doi.org/10.4238/gmr. 15017188

Hotamisligil GS (2010) Endoplasmic reticulum stress and the inflammatory basis of metabolic disease. Cell 140:900-917. https://doi. org/10.1016/j.cell.2010.02.034

Hu R, Xie XY, Xu SK, Wang YN, Jiang M, Wen LR, Lai W, Guan L (2017) PM2.5 exposure elicits oxidative stress responses and mitochondrial apoptosis pathway activation in $\mathrm{HaCaT}$ keratinocytes.
Chin Med J 130:2205-2214. https://doi.org/10.4103/03666999.212942

Jakobsen CH, Størvold GL, Bremseth H, Follestad T, Sand K, Mack M, Olsen KS, Lundemo AG, Iversen JG, Krokan HE, Schønberg SA (2008) DHA induces ER stress and growth arrest in human colon cancer cells: associations with cholesterol and calcium homeostasis. J Lipid Res 49:2089-2100. https://doi.org/10.1194/ jlr.M700389-JLR200

Jeong JW, Cha HJ, Han MH, Hwang SJ, Lee DS, Yoo JS, Choi IW, Kim S, Kim HS, Kim GY, Hong SH, Park C, Lee HJ, Choi YH (2017) Spermidine protects against oxidative stress in inflammation models using macrophages and zebrafish. Biomol Ther. https ://doi.org/10.4062/biomolther.2016.272

Jung S, Lim J, Kwon S, Jeon S, Kim J, Lee J, Kim S (2017) Characterization of particulate matter from diesel passenger cars tested on chassis dynamometers. J Environ Sci 54:21-32. https://doi. org/10.1016/j.jes.2016.01.035

Jux B, Kadow S, Luecke S, Rannug A, Krutmann J, Esser C (2011) The aryl hydrocarbon receptor mediates UVB radiation-induced skin tanning. J Investig Dermatol 131:203-210. https://doi. org/10.1038/jid.2010.269

Kaneto H, Matsuoka TA, Nakatani Y, Kawamori D, Miyatsuka T, Matsuhisa M, Yamasaki Y (2005) Oxidative stress, ER stress, and the JNK pathway in type 2 diabetes. J Mol Med 83:429-439. https:// doi.org/10.1007/s00109-005-0640-x

Kim HB, Yoo BS (2016) Propolis inhibits UVA-induced apoptosis of human keratinocyte $\mathrm{HaCaT}$ cells by scavenging ROS. Toxicol Res 32:345-351. https://doi.org/10.5487/TR.2016.32.4.345

Kim KE, Cho D, Park HJ (2016) Air pollution and skin diseases: adverse effects of airborne particulate matter on various skin diseases. Life Sci 152:126-134. https://doi.org/10.1016/j. lfs.2016.03.039

Kouassi KS, Billet S, Garçon G, Verdin A, Diouf A, Cazier F, Djaman J, Courcot D, Shirali P (2010) Oxidative damage induced in A549 cells by physically and chemically characterized air particulate matter (PM2.5) collected in Abidjan, Côte d'Ivoire. J Appl Toxicol 30:310-320. https://doi.org/10.1002/jat.1496

Krutmann J, Liu W, Li L, Pan X, Crawford M, Sore G, Seite S (2014) Pollution and skin: from epidemiological and mechanistic studies to clinical implications. J Dermatol Sci 76:163-168. https://doi. org/10.1016/j.jdermsci.2014.08.008

Laing S, Wang G, Briazova T, Zhang C, Wang A, Zheng Z, Gow A, Chen AF, Rajagopalan S, Chen LC, Sun Q, Zhang K (2010) Airborne particulate matter selectively activates endoplasmic reticulum stress response in the lung and liver tissues. Am J Physiol Cell Physiol 299:C736-C749. https://doi.org/10.1152/ajpcell.00529 .2009

Lee BK, Smith TJ, Garshick E, Natkin J, Reaser P, Lane K, Lee HK (2005) Exposure of trucking company workers to particulate matter during the winter. Chemosphere 61:1677-1690. https://doi. org/10.1016/j.chemosphere.2005.03.091

Lee J, Giordano S, Zhang J (2012) Autophagy, mitochondria and oxidative stress: cross-talk and redox signalling. Biochem J 441:523540. https://doi.org/10.1042/BJ20111451

Lee CW, Lin ZC, Hu SC, Chiang YC, Hsu LF, Lin YC, Lee IT, Tsai MH, Fang JY (2016) Urban particulate matter down-regulates filaggrin via COX2 expression/PGE2 production leading to skin barrier dysfunction. Sci Rep 6:27995. https://doi.org/10.1038/ srep27995

Lee YK, Kim SW, Park JY, Kang WC, Kang YJ, Khang D (2017) Suppression of human arthritis synovial fibroblasts inflammation using dexamethasone-carbon nanotubes via increasing caveolindependent endocytosis and recovering mitochondrial membrane potential. Int J Nanomed 12:5761-5779. https://doi.org/10.2147/ IJN.S142122 
Li D, Li L, Li P, Li Y, Chen X (2015) Apoptosis of HeLa cells induced by a new targeting photosensitizer-based PDT via a mitochondrial pathway and ER stress. Onco Targets Ther 8:703-711. https://doi. org/10.2147/OTT.S76370

Li Q, Kang Z, Jiang S, Zhao J, Yan S, Xu F, Xu J (2017) Effects of ambient fine particles PM2.5 on human HaCaT cells. Int J Environ Res Public Health 14:E72. https://doi.org/10.3390/ijerph1401 0072

Liu Q, Xu C, Ji GX, Liu H, Shao WT, Zhang CL, Gu A, Zhao P (2017) Effect of exposure to ambient PM2.5 pollution on the risk of respiratory tract diseases: a meta-analysis of cohort studies. J Biomed Res 31:130-142. https://doi.org/10.7555/JBR.31.20160071

Ly LD, Xu S, Choi SK, Ha CM, Thoudam T, Cha SK, Wiederkehr A, Wollheim CB, Lee IK, Park KS (2017) Oxidative stress and calcium dysregulation by palmitate in type 2 diabetes. Exp Mol Med 49:e291. https://doi.org/10.1038/emm.2016.157

Mei Y, Thompson MD, Cohen RA, Tong X (2013) Endoplasmic reticulum stress and related pathological processes. J Pharmacol Biomed Anal 1:1000107

Morita M, Naito Y, Yoshikawa T, Niki E (2016) Plasma lipid oxidation induced by peroxynitrite, hypochlorite, lipoxygenase and peroxyl radicals and its inhibition by antioxidants as assessed by diphenyl-1-pyrenylphosphine. Redox Biol 8:127-135. https://doi. org/10.1016/j.redox.2016.01.005

Nishitoh H (2012) CHOP is a multifunctional transcription factor in the ER stress response. J Biochem 151:217-219. https://doi. org/10.1093/jb/mvr143

Park JE, Piao MJ, Kang KA, Shilnikova K, Hyun YJ, Oh SK, Jeong YJ, Chae S, Hyun JW (2017) A Benzylideneacetophenone derivative induces apoptosis of radiation-resistant human breast cancer cells via oxidative stress. Biomol Ther 25:404-410. https://doi. org/10.4062/biomolther.2017.010

Piao MJ, Kim KC, Choi JY, Choi J, Hyun JW (2011) Silver nanoparticles down-regulate Nrf2-mediated 8-oxoguanine DNA glycosylase 1 through inactivation of extracellular regulated kinase and protein kinase B in human Chang liver cells. Toxicol Lett 207:143-148. https://doi.org/10.1016/j.toxlet.2011.09.002

Ryter SW, Cloonan SM, Choi AM (2013) Autophagy: a critical regulator of cellular metabolism and homeostasis. Mol Cells 36:7-16. https://doi.org/10.1007/s10059-013-0140-8

Schrock JM, Spino CM, Longen CG, Stabler SM, Marino JC, Pasternak GW, Kim FJ (2013) Sequential cytoprotective responses to sigma1 ligand-induced endoplasmic reticulum stress. Mol Pharmacol 84:751-762. https://doi.org/10.1124/mol.113.087809

Soeur J, Belaïdi JP, Chollet C, Denat L, Dimitrov A, Jones C, Perez P, Zanini M, Zobiri O, Mezzache S, Erdmann D, Lereaux G, Eilstein J, Marrot L (2017) Photo-pollution stress in skin: traces of pollutants (PAH and particulate matter) impair redox homeostasis in keratinocytes exposed to UVA1. J Dermatol Sci 86:162-169. https ://doi.org/10.1016/j.jdermsci.2017.01.007
Song S, Lee K, Lee YM, Lee JH, Lee SI, Yu SD, Paek D (2011) Acute health effects of urban fine and ultrafine particles on children with atopic dermatitis. Environ Res 111:394-399. https://doi. org/10.1016/j.envres.2010.10.010

Su R, Jin X, Zhang W, Li Z, Liu X, Ren J (2017) Particulate matter exposure induces the autophagy of macrophages via oxidative stress-mediated PI3K/AKT/mTOR pathway. Chemosphere 167:444-453. https://doi.org/10.1016/j.chemosphere.2016.10.024

Tanida I, Minematsu-Ikeguchi N, Ueno T, Kominami E (2005) Lysosomal turnover, but not a cellular level, of endogenous LC3 is a marker for autophagy. Autophagy 1:84-91

Vogel CF, Chang WL, Kado S, McCulloh K, Vogel H, Wu D, Haarmann-Stemmann T, Yang G, Leung PS, Matsumura F, Gershwin ME (2016) Transgenic overexpression of aryl hydrocarbon receptor repressor (AhRR) and AhR-mediated induction of CYP1A1, cytokines, and acute toxicity. Environ Health Perspect 124:10711083. https://doi.org/10.1289/ehp.1510194

Wang M, Wey S, Zhang Y, Ye R, Lee AS (2009) Role of the unfolded protein response regulator GRP78/BiP in development, cancer, and neurological disorders. Antioxid Redox Signal 11:2307-2316. https://doi.org/10.1089/ARS.2009.2485

Wang Z, Liu D, Varin A, Nicolas V, Courilleau D, Mateo P, Caubere C, Rouet P, Gomez AM, Vandecasteele G, Fischmeister R, Brenner C (2016) A cardiac mitochondrial cAMP signaling pathway regulates calcium accumulation, permeability transition and cell death. Cell Death Dis 7:e2198. https://doi.org/10.1038/cddis.2016.106

Wang Y, Xiong L, Tang M (2017) Toxicity of inhaled particulate matter on the central nervous system: neuroinflammation, neuropsychological effects and neurodegenerative disease. J Appl Toxicol 37:644-667. https://doi.org/10.1002/jat.3451

Wei H, Feng Y, Liang F, Cheng W, Wu X, Zhou R, Wang Y (2017) Role of oxidative stress and DNA hydroxymethylation in the neurotoxicity of fine particulate matter. Toxicology 380:94-103. https ://doi.org/10.1016/j.tox.2017.01.017

Xu C, Bailly-Maitre B, Reed JC (2005) Endoplasmic reticulum stress: cell life and death decisions. J Clin Investig 115:2656-2664. https ://doi.org/10.1172/JCI26373

Yao J, Jiao R, Liu C, Zhang Y, Yu W, Lu Y, Tan R (2016) Assessment of the cytotoxic and apoptotic effects of chaetominine in a human leukemia cell line. Biomol Ther 24:147-155. https://doi. org/10.4062/biomolther.2015.093

Zhao J, Gao Z, Tian Z, Xie Y, Xin F, Jiang R, Kan H, Song W (2013) The biological effects of individual-level $\mathrm{PM}(2.5)$ exposure on systemic immunity and inflammatory response in traffic policemen. Occup Environ Med 70:426-431. https://doi.org/10.1136/ oemed-2012-100864

Zhou ZX, Shao T, Qin MN, Miao XY, Chang Y, Sheng W, Wu FS, Yu YJ (2017) The effects of autophagy on vascular endothelial cells induced by airborne PM2.5. J Environ Sci. https://doi. org/10.1016/j.jes.2017.05.019 